\title{
Stratigraphic correlation potential of the Ediacaran palaeopascichnids
}

\section{Potencial de correlación estratigráfica de los paleopasciquínidos del Ediacárico}

\author{
A.V. Kolesnikov ${ }^{1,2,3}$ \\ ${ }^{1}$ Geological Institute, Russian Academy of Sciences, Pygevsky 7, Moscow 119017, Russia. Email: anton.kolesnikov@icloud.com; \\ ORCID ID: https://orcid.org/0000-0003-1028-9082 \\ ${ }^{2}$ Trofimuk Institute of Petroleum Geology and Geophysics of Siberian Branch Russian Academy of Sciences, prospekt \\ Akademika Koptyuga 3, Novosibirsk 630090, Russia \\ ${ }^{3}$ Moscow State Pedagogical University, Faculty of Geography, Kibalchicha str. 16, Moscow 129626, Russia
}

\begin{abstract}
For more than forty years, palaeopascichnids represented an enigmatic group of macroscopic fossils, which are characterised by substantial differences in preservation leading to no consistent diagnosis for these organisms. Numerically abundant palaeopascichnid fossils are globally distributed in Ediacaran sequences of the East European Platform, Avalonia, South China, Siberia and Australia. In light of new perspective to reanimate the 'Vendian' as a formal upper series of the Ediacaran System, Palaeopascichnida is probably the only Ediacaran fossil group whose stratigraphic range spans almost the entire 'Vendian Series'. Furthermore, it has been considered that palaeopascichnids are among the oldest known macro organisms with an agglutinated skeleton; its presence puts emphasis on this group in terms of Ediacaran biostratigraphy and geological correlation and paves the way for the reexamination of other skeletal palaeopascichnid-like fossils.
\end{abstract}

Keywords: Orbisiana; Palaeopascichnus; Yelovichnus; Palaeopascichnida; Ediacaran; Vendian.

\section{RESUMEN}

Durante más de cuarenta años, los paleopasciquínidos han representado un grupo enigmático de fósiles macroscópicos, caracterizados por diferencias sustanciales en la conservación, lo que no conduce a un diagnóstico consistente de estos organismos. Los fósiles de paleopasciquínidos se encuentran distribuidos globalmente en las secuencias ediacáricas de la Plataforma de Europa Oriental, Avalonia, China meridional, Siberia y Australia. A la luz de una nueva perspectiva para reanimar el "Véndico" como una serie superior formal del Sistema Ediacárico, los paleopasciquínidos son probablemente el único grupo fósil ediacárico cuyo rango estratigráfico abarca casi toda la "Serie del Véndico". Además, se ha considerado que los paleopasciquínidos se encuentran entre los macroorganismos más antiguos conocidos con un esqueleto aglutinado; su presencia enfatiza este grupo en términos de bioestratigrafía y correlación geológica ediacárica y allana el camino para la reexaminación de otros fósiles esqueléticos de tipo paleopasciquínido.

Palabras clave: Orbisiana; Palaeopascichnus; Yelovichnus; Paleopasciquínidos; Ediacárico; Véndico.

Citation / Cómo citar este artículo: Kolesnikov, A.V. (2019). Stratigraphic correlation potential of the Ediacaran palaeopascichnids. Estudios Geológicos 75(2): e102. https://doi.org/10.3989/egeol.43588.557.

Copyright: () 2019 CSIC. This is an open-access article distributed under the terms of the Creative Commons Attribution-Non Commercial (by-nc) Spain 4.0 License. 


\section{Introduction}

Palaeopascichnida (Fig. 1) represents an enigmatic group of macroscopic modular chain-like fossils, which are widespread in Ediacaran sequences. The term 'Palaeopascichnida' comes from the genus name Palaeopascichnus Palij (1976). The species Palaeopascichnus delicatus Palij was described from the Vendian (Ediacaran) deposits cropping out in Podolia (Ukraine), where the fossils have been preserved in the shape of series of fine furrows located in close proximity (negative epirelief) and also as narrow thin ridges (positive hyporelief; Palij, 1976). Palaeopascichnids were initially interpreted as either an ancient trace fossil of detritus feeders (Palij, 1976) or coprolites (Chistyakov et al., 1984). Later, Haines (2000) revised the group based on new material from Australia and came to the conclusion that they were algae. Stated on morphological similarities he compared Palaeopascichnida with the modern brown algal species Padina pavonica.

An alternative interpretation for palaeopascichnids is that they were benthic body fossils of unknown affinity (Gehling et al., 2005). It is important to mention the idea of Seilacher et al. (2003) who compared Palaeopascichnida with Xenophyophora, a modern deep-sea benthic protist. A while later, Antcliffe et al. (2011) considered that palaeopascichnids were made of several chambers that represented the remains of protists unrelated to Ediacara-like biota or xenophyophores and documented their low level of organisation. They stressed on the absence of pores and of any links between chambers, such as filaments or connecting tubes; moreover, they suggested an osmotrophic type of feeding through the agglutinated walls of chambers, alike agglutinated foraminifera.

Recently, it has been proved that the Ediacaran species Palaeopascichnus linearis represents the oldest known macroscopic organism with an agglutinated skeleton, which has close affinity with modern xenophyophore organisms such as Aschemonella monile or Psammina zonaria (Kolesnikov et al., 2018a). The presence of agglutinated macroscopic skeleton in Precambrian time significantly changes our view on Ediacaran palaeobiology, taphonomy and biostratigraphy. For the moment, the group Palaeopascichnida may include several species and morphotypes: type species Palaeopascichnus delicatus (Fig. 1A); Palaeopascichnus linearis (Fig. 1B, C); Yelovichnus gracilis (Fig. 1C); Orbisiana simplex (Fig. 1D); foam-like (Fig. 1E) and spiral-like (Fig. 1F) multichambered structures. Nevertheless, the fossils assigned to palaeopascichnids, such as Orbisiana or Yelovichnus (Fig. 1) are still characterised by differences in style of preservation leading to no consistent diagnosis for them.

\section{Palaeopascichnids in space and time}

Despite that the group Palaeopascichnida is still awaiting for official revision, the recent discoveries of agglutinated skeleton puts emphasis on this group of fossils in terms of biostratigraphic significance for the Ediacaran and terminal Ediacaran-Cambrian sequences. As an example of potential using palaeopascichnid skeletal fossils in stratigraphy and geological correlation finds itself in proposed 'Vendian Series', as a formal upper series of the Ediacaran System (Grazhdankin \& Maslov, 2015). It is suggested by D.V. Grazhdankin and A.V. Maslov that Vendian Series can be subdivided into Laplandian, Redkinian, Belomorian and Kotlinian stages which are typified by regional stratigraphic units of the Vendian sedimentary sequences of the East European Platform. As we can see (Fig. 2), Palaeopascichnus linearis is probably the only species meeting the criteria of a Vendian Series index-taxon whose stratigraphic range spans almost the entire series. The oldest representative of this species is found in the Member 2 of the Lantian Formation in South China (Yuan et al., 2011), whereas the youngest Palaeopascichnus linearis occurs in the uppermost part of the Ediacaran Zigan Formation in South Urals (Kolesnikov \& Bobkov, 2019), which correlates to a similar level of the Cambrian GSSP in Newfoundland (Narbonne et al., 1987). The type species Palaeopascichnus delicatus demonstrates a narrower stratigraphic range; it is distributed mainly in 'Belomorian' and 'Kotlinian' stages (Fig. 2), whereas the species Yelovichnus gracilis appears in 'Belomorian' time only. Orbisiana simplex and its similar foam-like chambered structures are another representatives of palaeopascichnid-like organisms (Kolesnikov et al., 2018b), and have a bit narrower (compared with $P$. linearis) stratigraphic range 

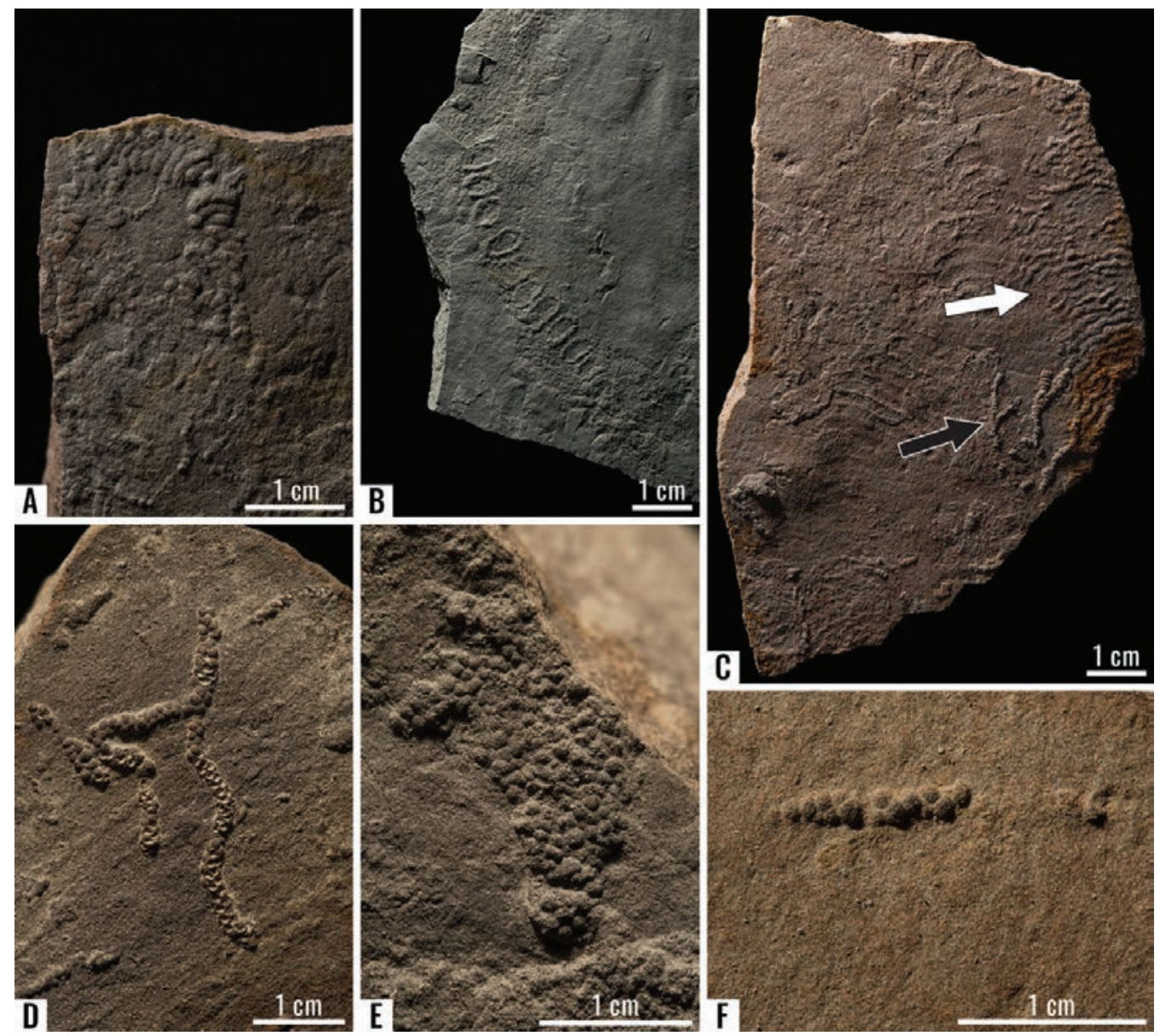

Figure 1.-Biological diversity of palaeopascichnids from the Ediacaran Verkhovka Formation of the White Sea area: A. Palaeopascichnus delicatus, Winter Coast; B. Palaeopascichnus linearis, Winter Coast; C. Palaeopascichnus linearis (marked by black arrow) and Yelovichnus gracilis (white arrow) on the same bedding surface, Winter Coast; D. Orbisiana simplex preserved on erosional surface, Syuzma River; E-F. foam-like (E) and spiral-like (F) orbisianamorph structures, Syuzma River. The illustrated material is reposited in the Trofimuk Institute of Petroleum Geology and Geophysics SB RAS in Novosibirsk, Russia.

starting from the Redkinian Stage and continuing to the transitional interval of late Ediacaran and early Cambrian. However, there are also spiral-like orbisianamorphs known from the White Sea area, which, along with Yelovichnus, are known only from the Belomorian Stage on the East European Platform.

Today, the palaeopascichnids are one of the most abundant macroscopic Ediacaran fossils, distributed globally. The group Palaeopascichnida was not affected by the Kotlinian Crisis (Kolesnikov et al., 2015); it demonstrates a wide numerical distribution in the geological sections of the Kanilovka Group in Podolia, Sylvitsa Group in Central Urals, Asha Group in South Urals and Khorbusuonka Group in Olenek Uplift, which are referred to the transitional and crisis intervals represented by Kotlinian regional stage and its stratigraphic analogues. At the moment, palaeopascichnids are distributed globally and occurred across the entire East European Platform (Finnmark, south-eastern slope of the Baltic Shield, Southeast White Sea area, Moscow and Mezen basins, Central and South Urals, Podolia), as well as in South China, Avalonia (Newfoundland, Wales), India (Tethys Himalaya), Australia (Adelaide Rift Complex), and Siberia (Olenek Uplift, Uchur-Maya Region) (Palij, 1976; Fedonkin, 1985; Cope, 1982; Narbonne et al., 1987; Haines, 2000; Parcha \& Pandey, 2011; Yuan et al., 2011; Ivantsov, 2017; Jensen et al., 2018; Kolesnikov et al., 2018a, 2018b). 


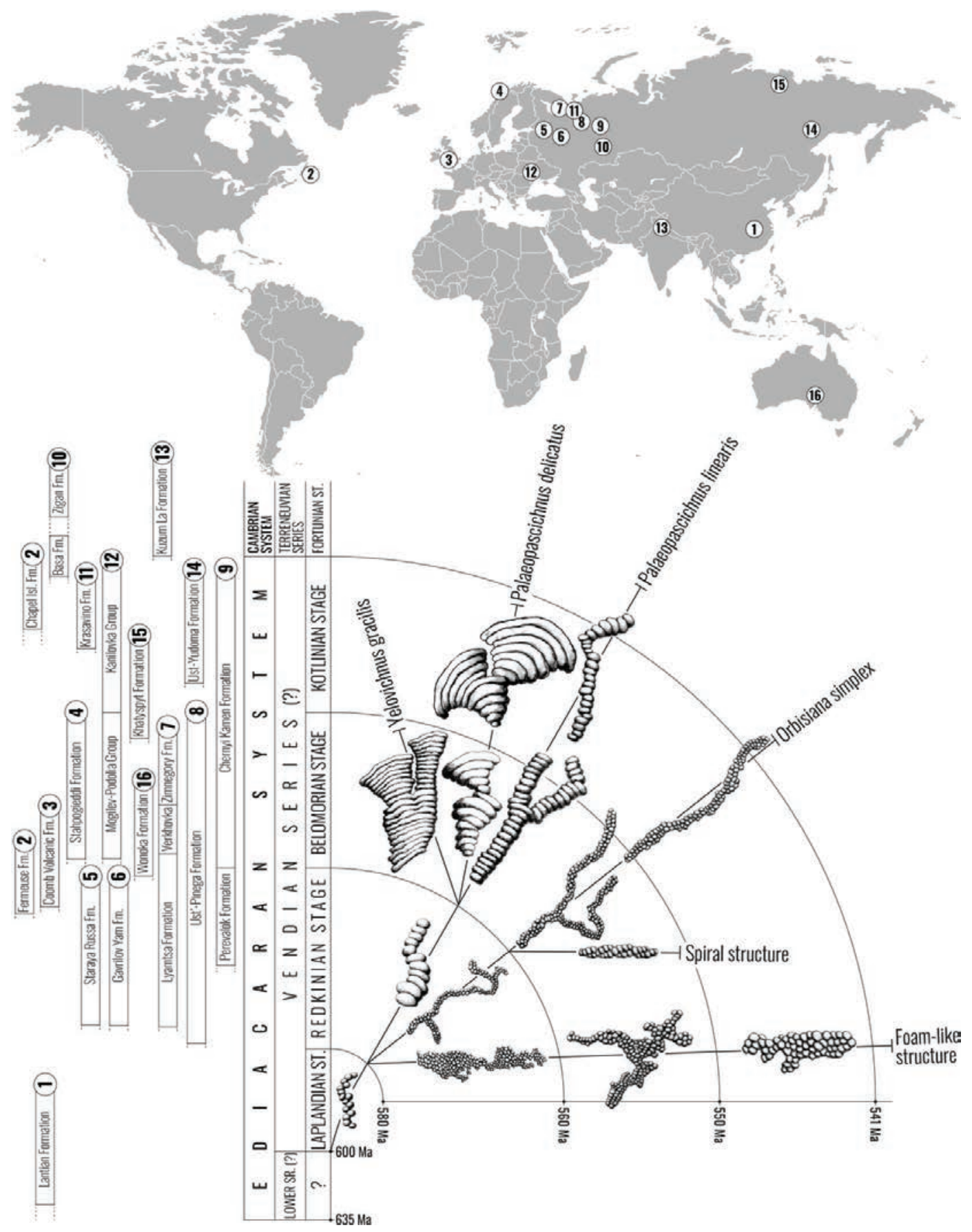

Figure 2.-Palaeopascichnids in space and time: 1. - Piyuancun, Lantian, South China; 2. Newfoundland, Canada: 3. Wales, United Kingdom; 4. Finnmark, Norway; 5. Ladoga Basin, Russia; 6. Moscow Basin, Russia; 7. White Sea area, Russia; 8. Vychegda Basin, Russia; 9. Central Urals, Russia; 10. South Urals, Russia; 11. Mezen Basin, Russia; 12. Podolia, Ukraine; 13. Tethys Himalaya, India; 14. Uchur-Maya Region of Siberia, Russia; 15. Olenek Uplift of Siberia, Russia; 16. Flinders Ranges, Australia.

\section{Conclusions}

The group Palaeopascichnida is presented globally in Ediacaran and transitional Ediacaran-Cambrian sedimentary sequences. Perhaps, it is the only Ediacaran macroscopic fossil group that has a good chance of using in geological correlation and stratigraphic subdivision of Ediacaran System, however, up to this 
time it is awaiting for systematic revision. Thus, the reassessment of the group of Palaeopascichnida apparently should provide important implications for classification of Ediacaran organisms and for Precambrian biostratigraphy using macrofossils.

\section{ACKNOWLEDGEMENTS}

This research has been supported by the Russian Science Foundation [grant No. 19-77-00028]. Author thanks D.V. Grazhdankin for his helpful and constructive comments.

\section{References}

Antcliffe, J.B.; Gooday, A.J. \& Brasier, M.D. (2011). Testing the protozoan hypothesis for Ediacaran fossils: A developmental analysis of Palaeopascichnus. Palaeontology, 54: 1157-1175. https://doi. org/10.1111/j.1475-4983.2011.01058.x

Chistyakov, B.G.; Kalmykova, N.A.; Nesov, L.A. \& Suslov, G.A. (1984). The occurrence of Vendian strata in the middle reaches of the Onega River and a possibility of tunicates (Tunicata: Chordata). existence in the Precambrian. Vestnik Leningradskogo Universiteta, Seriya Geologicheskaya, 6: 11-19 [in Russian].

Cope, J.C.W. (1982). Precambrian fossils of the Carmarthen area, Dyfed. Nature in Wales, 1 (2): 11-16.

Fedonkin, M.A. (1980). Vendian fauna in the north of the Russian Platform. In: The Vendian System: argumentation of historical geology and palaeontology (Sokolov, B.S. \& Ivanovski, A.B.; Eds.), Nauka, Moscow, 112-117. [in Russian]

Gehling, J.G.; Droser, M.L.; Jensen, S. \& Runnegar, B.N. (2005). Ediacara Organisms: Relating Form to Function. In: Evolving Form and Function: Fossils and Development: Proceedings of a symposium honouring Adolph Seilacher for his contributions to palaeontology in celebration of his 80th birthday (Briggs, D.E.G.; Ed.), Peabody Museum of Natural History, Yale University, 43-66.

Grazhdankin, D.V. \& Maslov, A.V. (2015). The room for the Vendian in the International Chronostratigraphic Chart. Russian Geology and Geophysics, 56: 549-559. https://doi.org/10.1016/j.rgg.2015.03.007

Haines, P.W. (2001). Problematic fossils in the late Neoproterozoic Wonoka Formation, South Australia. Precambrian Research, 100: 97-108. https://doi.org/ 10.1016/S0301-9268(99)00070-4

Ivantsov, A.Yu. (2017). Finds of Ediacaran-type fossils in Vendian deposits of the Yudoma Group, eastern
Siberia. Doklady Earth Sciences, 472: 143-146. https://doi.org/10.1134/S1028334X17020131

Jensen, S.; Högström, A.E.S.; Høyberget, M.; Meinhold, G.; McIlroy, D.; Ebbestad, J.O.R.; Taylor, W.L.; Agic, H. \& Palacios, T. (2018). New occurrences of Palaeopascichnus from the Stáhpogieddi Formation, Arctic Norway, and their bearing on the age of Varanger Ice Age. Canadian Journal of Earth Sciences, 55: 12531261. https://doi.org/10.1139/cjes-2018-0035

Kolesnikov, A.V.; Marusin, V.V.; Nagovitsin, K.E.; Maslov, A.V. \& Grazhdankin, D.V. (2015). Ediacaran biota in the aftermath of the Kotlinian Crisis: Asha Group of the South Urals. Precambrian Research, 263: 59-78. https://doi.org/10.1016/j.precamres.2015.03.011

Kolesnikov, A.V.; Rogov, V.I.; Bykova, N.V.; Danelian, T.; Clausen, S.; Maslov, A.V. \& Grazhdankin, D.V. (2018a). The oldest skeletal macroscopic organism Palaeopascichnus linearis. Precambrian Research, 316: 24-37. https://doi.org/10.1016/j.precamres.2018.07.017

Kolesnikov, A.V.; Liu, A.G.; Danelian, T. \& Grazhdankin, D. (2018b). A reassessment of the problematic Ediacaran genus Orbisiana Sokolov 1976. Precambrian Research, 316: 197-205. https:// doi.org/10.1016/j.precamres.2018.08.011

Kolesnikov, A.V. \& Bobkov, N.I. (2019). Revisiting the age of the Asha Group in the South Urals. Estudios Geológicos 75(2): e103. https://doi.org/10.3989/ egeol.43590.558

Narbonne, G.M.; Myrow, P.M.; Landing, E. \& Anderson, M.M. (1987). A candidate stratotype for the Precambrian-Cambrian boundary, Fortune Head, Burin Peninsula, south-eastern Newfoundland. Canadian Journal of Earth Sciences, 24: 1277-1293. https:// doi.org/10.1139/e87-124

Palij, V.M. (1976). Remains of soft-bodied animals and trace fossils from the Upper Precambrian and Lower Cambrian of Podolia. In: Palaeontology and stratigraphy of Upper Precambrian and Lower Cambrian of southeast East European Platform (Schul'ga, P.L.; Ed.), Naukova dumka, Kiev, 63-76. [in Russian]

Parcha, S.K. \& Pandey, S. (2011). Ichnofossils and their significance in the Cambrian successions of the Parahio Valley in the Spiti Basin, Thethys Himalaya, India. Journal of Asian Earth Sciences, 42: 1097-1116. https://doi.org/10.1016/j.jseaes.2011.04.028

Seilacher, A.; Grazhdankin, D. \& Legouta, A. (2003). Ediacaran biota: the dawn of animal life on the shadow of giant protists. Paleontological Research, 7 (1): 43-54. https://doi.org/10.2517/prpsj. 7.43

Yuan, X.; Chen, Z.; Xiao, S.; Zhou, C. \& Hua, H. (2011). An early Ediacaran assemblage of macroscopic and morphologically differentiated eukaryotes. Nature, 470: 390-393. https://doi.org/10.1038/nature09810 